\title{
PENJADWALAN PEKERJAAN PROYEK STRUKTUR ATAS DENGAN MENGGUNAKAN REPETITIVE SCHEDULING METHOD
}

\author{
Fauzan A. Sangadji ${ }^{1}$, Wiyoga Triharto ${ }^{2}$, Bambang Perkasa Alam ${ }^{3}$ \\ ${ }^{1}$ Universitas Indraprasta PGRI, Program Studi Arsitektur \\ aan.sangadji@gmail.com \\ ${ }^{2}$ Universitas Indraprasta PGRI, Program Studi Arsitektur \\ wiyogatriharto@yahoo.com \\ ${ }^{3}$ Universitas Indraprasta PGRI, Program Studi Arsitektur \\ bambang.perkasaalam@unindra.ac.id
}

\begin{abstract}
Growth in the construction sector will have a very positive impact on economic growth both directly and indirectly. For this reason, it is necessary to have a good and efficient time control management. In this research, rescheduling will be conducted using the Repetitive Scheduling Method. From the rescheduling results, it was found that scheduling the project could be completed in a much faster time frame. It takes 5 weeks from the 10 weeks schedule plan.
\end{abstract}

Key Words: Repetitive Scheduling Method, Scheduling, Construction Projects, Typical Construction

\begin{abstract}
Abstrak : Pertumbuhan di bidang konstruksi akan sangat berdampak positif terhadap pertumbuhan ekonomi baik secara langsung maupun tidak langsung. Untuk itu sangat diperlukan adanya manajemen pengendalian waktu yang baik dan efisien. Dalam penelitian ini akan dilakukan penjadwalan ulang dengan metode penjadwalan Repetitive Scheduling Method. Dari hasil penjadwalan ulang tersebut didapatkan bahwa penjadwalan proyek tersebut dapat selesai dalam kurun waktu yang jauh lebih cepat, yakni 5 minggu dari rencana pekerjaan 10 minggu.

Kata Kunci : Repetitive Scheduling Method, Penjadwalan, Proyek Konstruksi, Konstruksi Tipikal
\end{abstract}

\section{PENDAHULUAN}

Pembangunan infrastruktur akan dapat berdampak positif pada pertumbuhan ekonomi, baik secara langsung maupun tidak langsung. Infrastruktur sendiri merupakan prasyarat bagi sektor-sektor lain untuk berkembang serta sebagai sarana penciptaan hubungan antara satu dan yang lainnya. Pemberdayaan sumber daya untuk membangun infrastruktur akan memicu proses ekonomi sehingga menimbulkan penggandaan dampak ekonomi maupun sosial.

Dengan adanya pertumbuhan dibidang konstruksi, maka dari itu disini sangat diperlukan adanya manajemen pengendalian waktu bagi proyek konstruksi yang disamping mempertajam prioritas juga mengusahakan peningkatan efisiensi dan efektivitas pengelola proyek agar tercapai hasil yang maksimal.

Selain manajemen pengendalian waktu juga harus diikuti dengan pelaksanaan proyek yang baik serta pemeliharaan yang terjadwal secara berkala, maka resiko sebuah proyek konstruksi mengalami kemunduran atau terlambat akan menjadi lebih kecil. Secara langsung hal tersebut akan mengurangi pembengkakan biaya yang akan dikeluarkan oleh proyek tersebut, serta pada akhirnya akan memberikan keuntungan tersendiri bagi para kontraktor sebagai penanggung jawab pelaksanaan dan pemeliharaan suatu proyek. Dan semua ini tidak terlepas karena untuk mencapai tujuan dari sebuah proyek konstruksi yaitu kesuksesan yang memenuhi kriteria waktu (jadwal), biaya (anggaran) dan juga mutu (kualitas).

Dalam perkembangan ilmu manajemen sekarang perencanaan waktu pekerjaan sangat tidak efektif jika dilakukan bertahap dimulai dari struktur, arsitektur dan pekerjaan mekanikal. Untuk itu perlu dilakukan tahapan paralel dalam menyelesaikan sebuah proyek dengan melakukan zoning. Tahapan ini sudah dikenal dengan nama Repetitive Scheduing Method (RSM).

Dalam artikel ini akan dijelaskan penggunaan dan perbandingan schedule s-curve dan metode RSM pada proyek pembangunan Proyek "Park View Condominium Apartement" di Detos, Depok. 


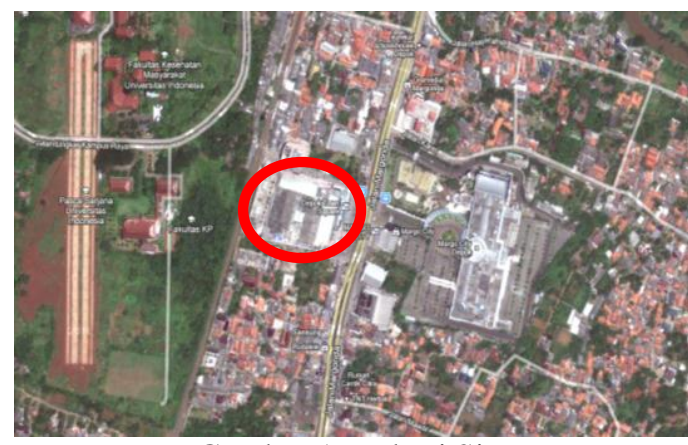

Gambar 1. Lokasi Site

Sumber : www.google.com, 2013

\section{Repetitive Scheduling Method (RSM)}

Repetitive Scheduling Method (RSM) adalah suatu metode penjadwalan yang pada umumnya dipergunakan untuk proyek yang memiliki kegiatan berulang. Metode ini mampu memperlihatkan pemanfaatan sumber daya, baik berupa tenaga kerja, peralatan maupun bahan tanpa terputus.

Metode penjadwalan berulang (RSM) menyediakan kerangka kerja penjadwalan terpadu yang berlaku untuk semua jenis proyek berulang. Aktivitas yang berulang dari satu unit ke unit yang lain menimbulkan kebutuhan yang sangat mendesak untuk penjadwalan proyek yang memungkinkan penggunaan sumber daya yang tidak terputus/ slag, misalnya para pekerja dari satu unit ke unit berikutnya, karena sering terjadi kebutuhan ini (penggunaan sumber daya yang tidak putus) yang menentukan waktu memulai aktivitas dan mempengaruhi seluruh durasi proyek. Oleh sebab itu, penggunaan sumber daya yang tidak terputus menjadi hal yang sangat penting dalam penjadwalan proyek.

\section{METODOLOGI}

Metode yang akan dilakukan adalah melakukan penjadwalan kembali pekerjaan proyek Park View Condominium Apartement dengan menggunan RSM.

Variabel yang akan dilakukan penjadwalan kembali terbatas pada pekerjaan Struktur Apartement lantai 4, 5 dan 6. Hal ini hanya sebagai contoh, namun penerapannya bisa dilakukan sampai lantai 18 karena bentuk struktur yang sama sampai dengan lantai tersebut.

Rincian kegiatan dalam pekerjaan struktur yang dilakukan adalah balok, kolom, plat lantai dan tangga. Sedangkan rincian kegiatan terdiri dari pembesian, bekisting dan pengecoran. Daerah pekerjaan akan dibagi menjadi 3 zone yakni A, B dan C. Pembagian Zone dapat dilihat di lampiran 1. Durasi waktu dari setiap kegiatan diambil berdasarkan hasil tinjauan pelaksanaan pekerjaan dilapangan proyek tersebut pada tahun 2013.

\section{HASIL DAN PEMBAHASAN \\ S-curve Rencana}

Berdasarkan schedule rencana pekerjaan proyek "Park View Condominium" pekerjaan struktur lantai 4 sampai dengan 6 akan dimulai pada 25 April 2012 dan selesai pada tanggal 1 Juli 2012 dengan durasi10 Minggu. S-curve dapat dilihat di lampiran 2.

\section{Hasil Analisis Dengan Metode RSM \\ 1. Struktur Balok Portal}
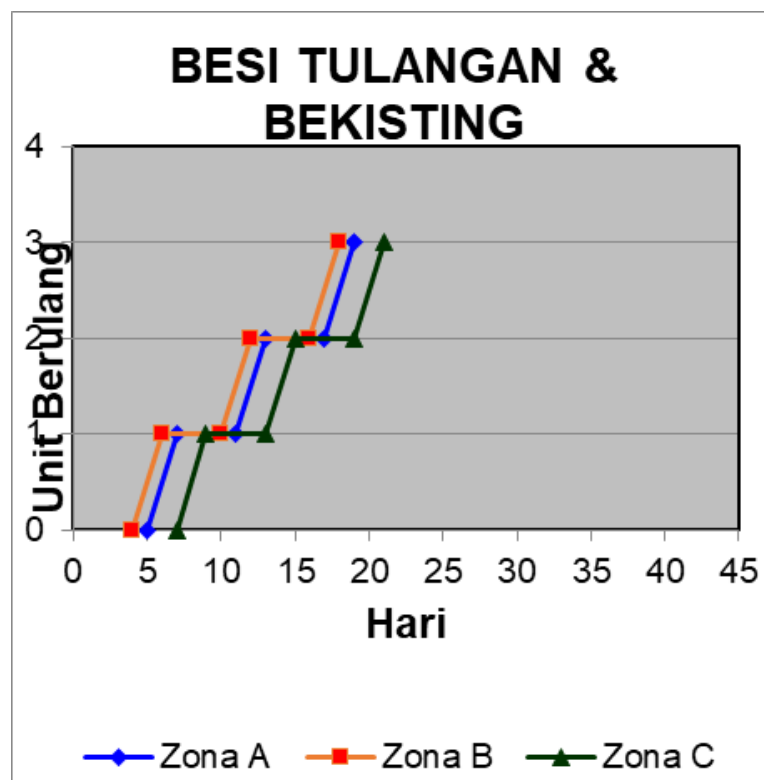

Gambar 2. Grafik Pemasangan Besi Tulangan dan Bekisting Struktur Balok Portal Sumber : Hasil Analisa

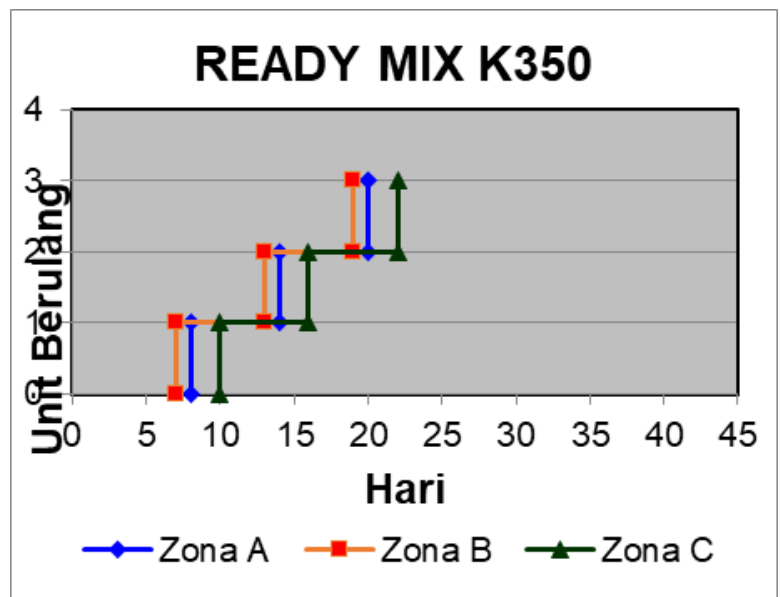

Gambar 3. Grafik Pekerjaan Pengecoran Struktur Balok Portal

Sumber : Hasil Analisa 
Berdasarkan gambar 2 dan gambar 3 pada grafik balok portal untuk lantai 4 , lantai 5 , dan lantai 6 terlihat bahwa rentang waktu pelaksanaan pekerjaan pemasangan besi tulangan dan bekisting adalah sama untuk zona A, zona B dan zona C. Jadi kedua kegiatan tersebut digambarkan dalam satu garis linier. Dari grafik tersebut dapat diketahui pula bahwa durasi pelaksanaan pekerjaan pemasangan besi tulangan dan bekisting pada zona $\mathrm{A}$, zona $\mathrm{B}$ dan zona $\mathrm{C}$ adalah sama yaitu 3 hari. Pelaksanaan pekerjaan ini pada zona A dilakukan sebelum pekerjaan tersebut selesai di zona B sehingga terlihat penumpukkan pekerjaan pada hari ke 5 dan 6,11 dan 12 serta 17 dan 18. Sedangkan pekerjaan pengecoran pada masing-masing zona dilakukan sehari setelah selesainya pemasangan besi tulangan dan bekisting. Meskipun pengecoran dapat dilakukan dan diselesaikan pada hari yang sama namun tetap terlihat adanya waktu tenggang selama 1 hari pada masing-masing zona dari selesainya pemasangan besi tulangan dan bekisting dengan pengecoran sehingga waktu pelaksanaan kegiatan dirasakan kurang efektif.

\section{Struktur Plat Lantai}

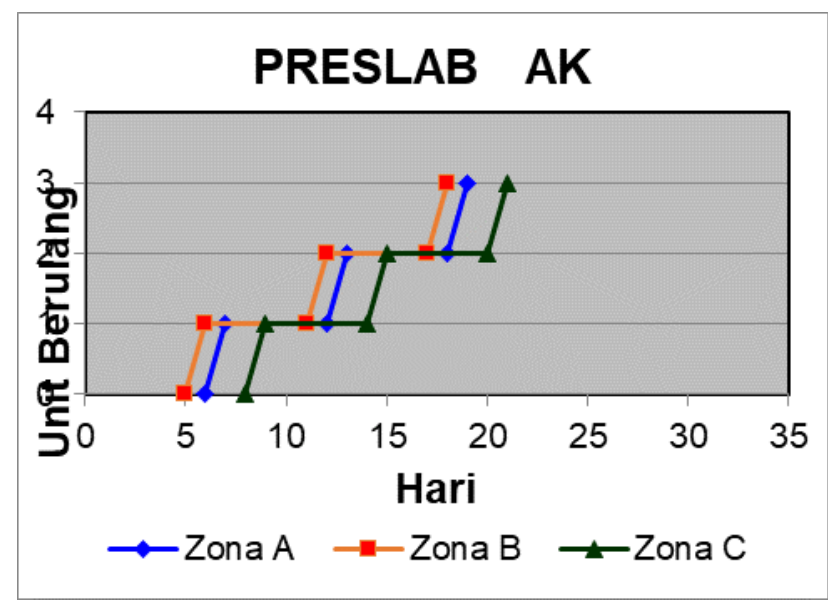

Gambar 4. Grafik Pemasangan Preslab AK Plat Lantai Sumber : Hasil Analisa

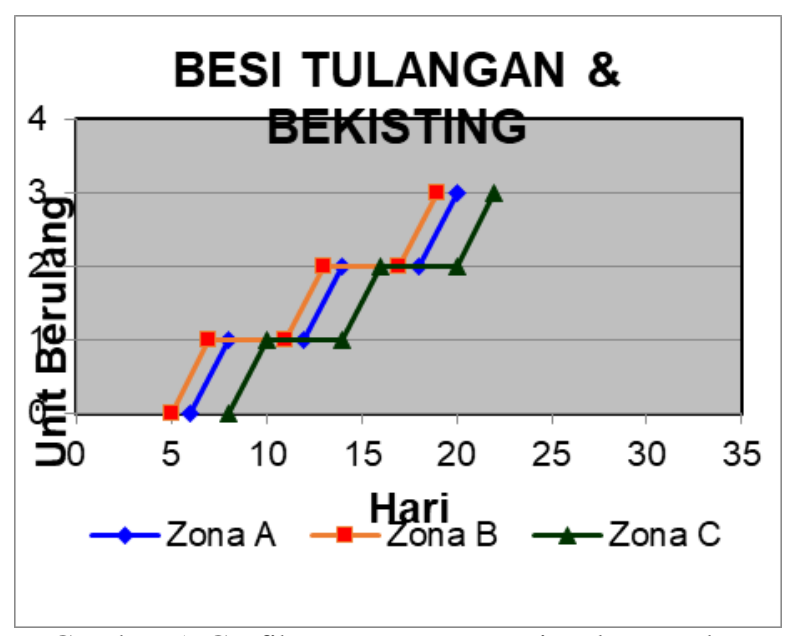

Gambar 5. Grafik Pemasangan Besi Tulangan dan Bekisting Plat Lantai

Sumber : Hasil Analisa

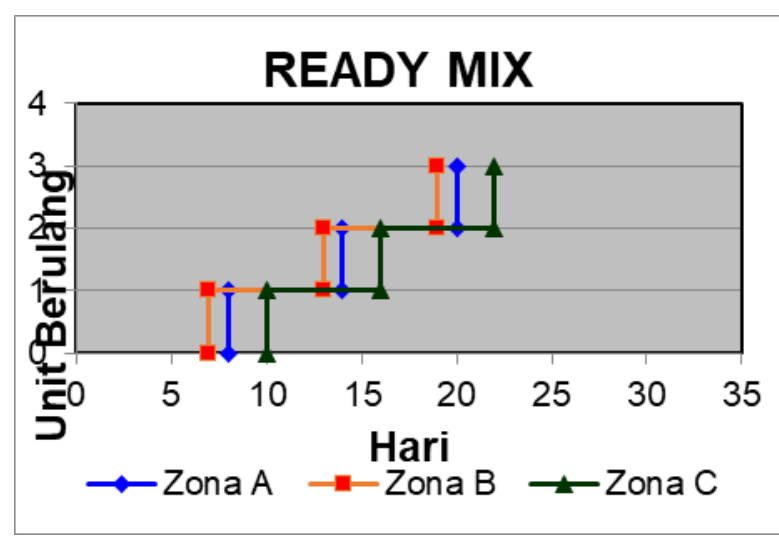

Gambar 6. Grafik Pemasangan Ready Mix Plat Lantai Sumber : Hasil Analisa

Berdasarkan gambar 4, gambar 5 dan gambar 6 pada grafik pekerjaan struktur plat lantai pada lantai 4, lantai 5 dan lantai 6 terlihat bahwa pekerjaan struktur tersebut terdiri dari preslab AK yang penyelesaiannya sama pada zona $\mathrm{A}$, zona $\mathrm{B}$ dan zona $\mathrm{C}$ yakni 2 hari. Terlihat pula terjadi penumpukan pekerjaan pada hari ke 6 dan 7, 12 dan 13 serta 18 dan 19 karena besi tulangan dan bekisting. Sedangkan penggunaan waktu pelaksanaan pengecoran sudah efektif yaitu segera setelah pemasangan besi tulangan dan bekisting. 


\section{Struktur Kolom}

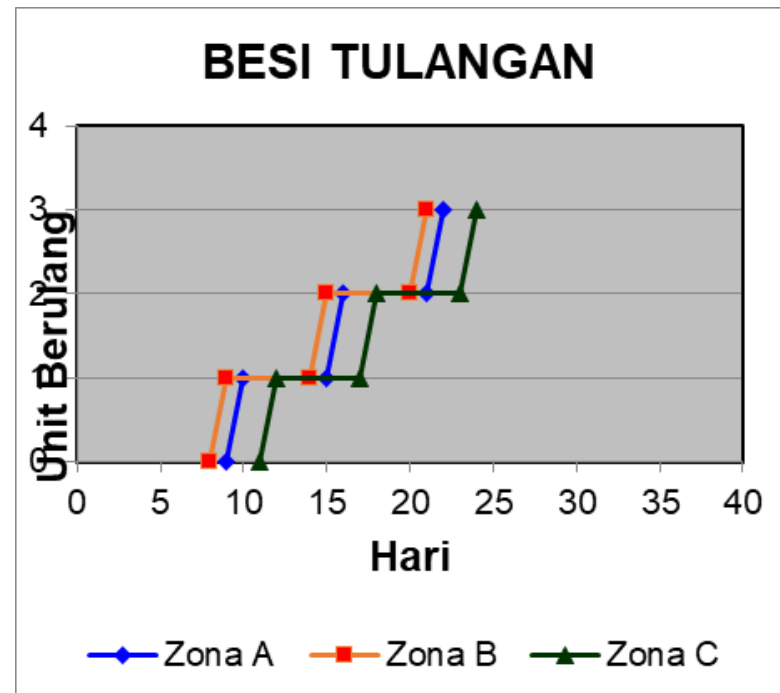

Gambar 7. Grafik Pemasangan Besi Tulangan Struktur Kolom

Sumber : Hasil Analisa

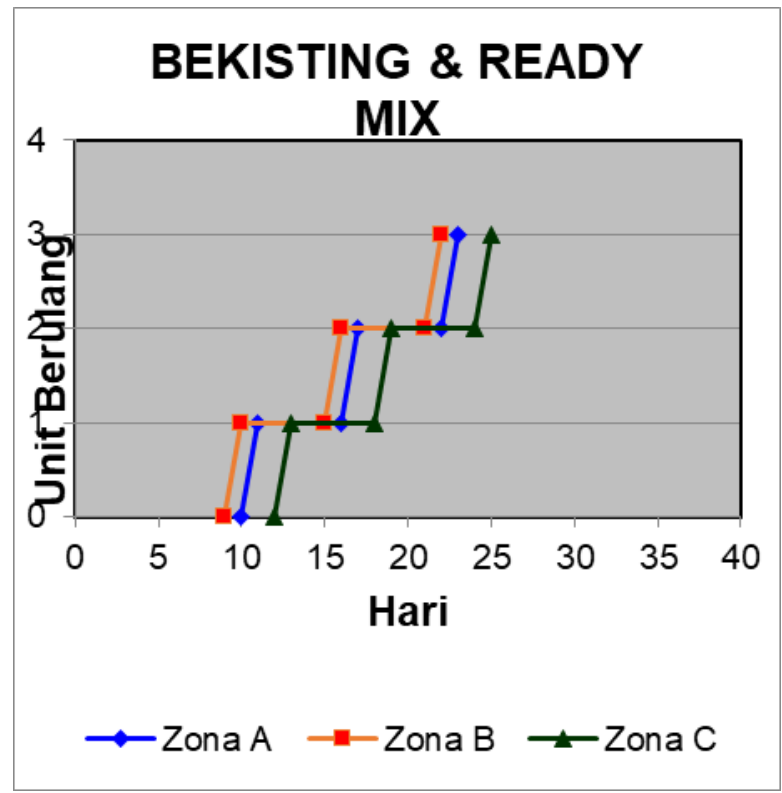

Gambar 8. Grafik Pemasangan Bekisting dan Ready Mix Struktur Kolom

Sumber : Hasil Analisa

Berdasarkan gambar 7 dan gambar 8 pada grafik pelaksanaan pekerjaan kolom yang terdiri dari pemasangan besi tulangan, bekisting dan pengecoran terlihat bahwa terdapat total waktu tenggang selama 2 hari pada pemasangan besi tulangan pada setiap zona $\mathrm{C}$ terhadap zona $\mathrm{B}$ dan terdapat waktu tenggang selama 1 hari pada pekerjaan bekisting dan pengecoran. Durasi pemasangan besi tulangan adalah 1 hari untuk masing-masing zona sedangkan durasi pekerjaan bekisting dan pengecoran untuk masing-masing zona tidaklah sama.

\section{Struktur Tangga}

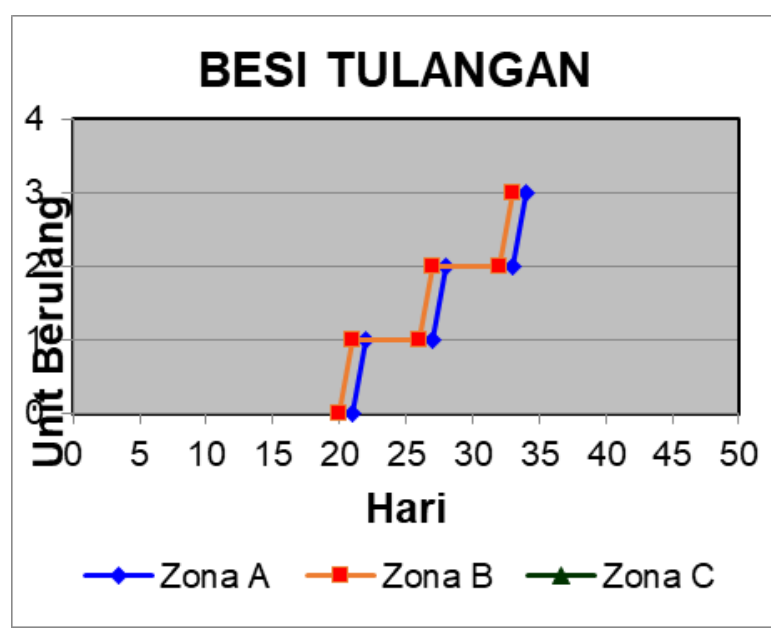

Gambar 9. Grafik Pemasangan Besi Tulangan Struktur Tangga

Sumber : Hasil Analisa

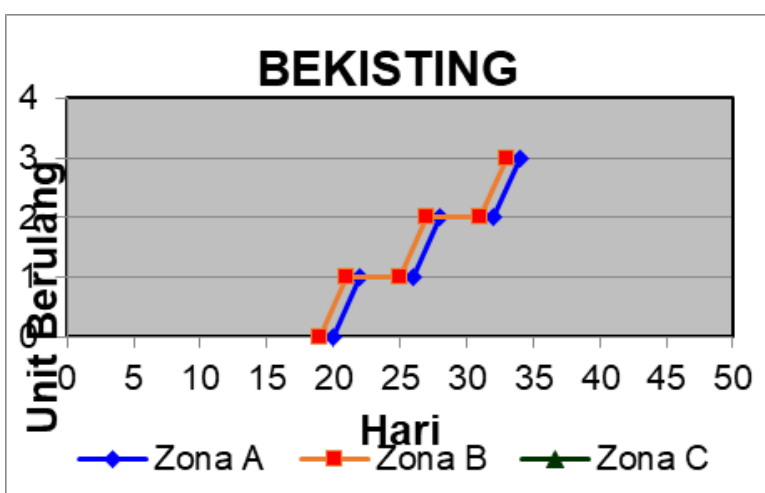

Gambar 10. Grafik Pemasangan Bekisting Struktur Tangga

Sumber : Hasil Analisa

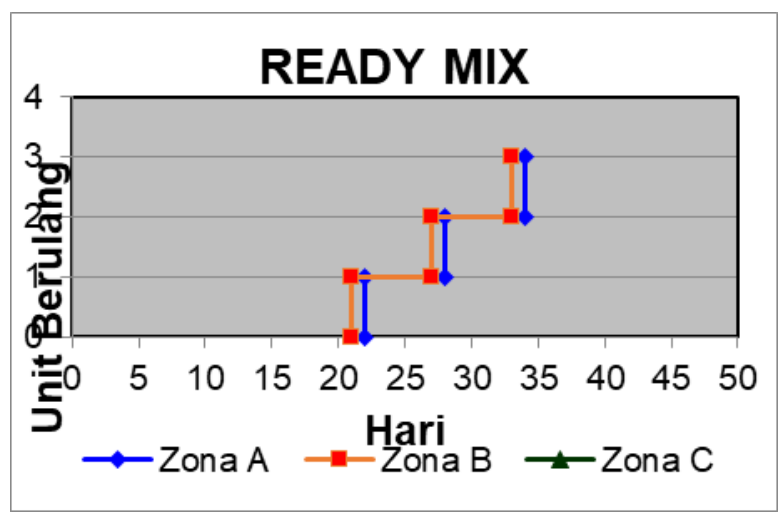

Gambar 11. Grafik Pemasangan Ready Mix Struktur Tangga

Sumber : Hasil Analisa

Berdasarkan gambar 9, gambar 10 dan gambar 11 pada grafik pelaksanaan pekerjaan struktur tangga yang terdiri dari pemasangan besi tulangan, bekisting dan pengecoran terlihat 
bahwa adanya penumpukan pekerjaan Bekisting pada hari ke 20 dan 21,26 dan 27 serta 32 dan 33. Namun pengecorannya cukup efektif karena dapat dilakukan dihari yang sama.

\section{PENUTUP}

\section{Kesimpulan}

Berdasarkan hasil penjadwalan dengan RSM diatas dapat dilihat bahwa pekerjaan struktur lantai 4, 5 dan 6 dapat selesai dalam waktu 33 hari atau sama dengan kurang dari 5 minggu. Hal ini menunjukkan bahwa metode ini dapat diselesaikan lebih cepat dari s-curve rencana yaitu 10 minggu.

Dengan menggunakan metode RSM ini memungkinkan penjadwal untuk melakukan pengurangan durasi dengan pertimbanganpertimbangan diatas dengan mudah karena penyajiannya yang sederhana dan mudah dipahami.

\section{Kritik}

1. Penggunaan RSM adalah suatu metode yang cukup efektif dalam menyajikan sebuah skema penjadwalan yang sederhana dan mudah dipahami. Namun penggunaan metode ini hanya dapat dilakukan untuk proyek yang berulang

2. Penggunaan sumber daya manusia pada penelitian ini diamsusikan memiliki tim yang banyak, karena dalam satu minggu pekerjaan dilakukan pada setiap lantai baik untuk pembesian, bekisting dan pengecoran untuk struktur balok, kolom, plat lantai dan tangga.

3. Biaya ataupun cashflow pekerjaan proyek tersebut sangat besar tiap minggunya, sehingga termin ataupun pendanaan proyek harus besar setiap minggunya.

\section{Saran}

Untuk melakukan penjadwalan dengan metode ini sangat dibutuhkan perencaan biaya, manajemen sumber daya manusia, manajemen pengadaan dan tata kelola area proyek yang baik. Manajemen pengadaan dan tata kelola area pekerjaan sangat diperlukan untuk meminimalisasi adanya keterlambatan pengadaaan barang dan ketersediaan lokasi proyek terhadap barang yang datang. Sebab keterlambatan pengadaan barang dapat menyebabkan keterlambatan pengerjaan sehingga menyebabkan pembengkakan biaya untuk pembayaran para pekerja dalam masa idle.

\section{DAFTAR PUSTAKA}

Sangadji, Fauzan A. 2013. PENJADWALAN PEKERJAAN PROYEK STRUKTUR ATAS DENGAN MENGGUNAKAN REPETITIVE SCHEDULING METHOD. Tugas Akhir Universitas Pancasila. Jakarta

Makmun Syadullah. 6 Januari 2019. Mengefektifkan Dampak Pembangunan Infrastruktur. Investor Daily

Robert B. Harris dan Photios G. Ioannou. 1998. Repetitive Scheduling Method. Michigan

Wiranata, Anak Agung. Juli 2009. PENGGUNAAN METODE PENJADWALAN BERULANG (REPETITIVE SCHEDULING METHOD) PADA PENGERJAAN PROYEK PERUMAHAN (Studi Kasus Pada Proyek Perumahan Beranda Mumbul). E-Jurnal Udayana.

Annis Nur Uzma. 2012. Penerapan Repetitive Scheduling Method Pada Penjadwalan Proyek Jalan Tubaan-Talisayan/ Dumaring, Provinsi Kalimantan Timur. Jurnal Institut Teknologi Sepuluh Nopember. Surabaya

S., Arikunto. 1993. Metode Penelitian. Rineka Cipta. Jakarta.

Ali, Tubagus H. 1995. Prinsip-Prinsip Network Planning. Jakarta: Gramedia Pustaka Utama.

Callahan, Michael T., Daniel G. Quackenbush, James E. Rowings. 1992. Construction Project Scheduling. Singapore: McGrawHill, Inc. 